Вісник Дніпропетровського університету. Біологія. Екологія. - 2008. - Вип. 16, т. 1. - С. 57-63. Visnyk of Dnipropetrovsk University. Biology. Ecology. - 2008. - Vol. 16, N 1. - P. 57-63.

УДК 582.34 : 581.9(47) : 526.44

С. В. Гапон

Полтавський державний педагогічний університет ім. В. Г. Короленка

\title{
ЧАСТОТА ТРАПЛЯННЯ МОХОПОДІБНИХ В ЕПІФІТНИХ ОБРОСТАННЯХ
}

\begin{abstract}
Охарактеризовано частоту трапляння мохоподібних епіфітних бріоугруповань широколистяних лісів долини р. Ворскла, подано їх еколого-біологічні особливості. Чіткої приуроченості видів до конкретних порід дерев не спостерігається, але характерним є деяке тяжіння Нурпит pallescens (Hedw.) P. Beauv., Platygyrium repens (Brid.) B.S.G., Bryum subelegans Kindb. до Quercus robur L., Radula complanata (L.) Dum., Leskeella nervosa (Brid.) Loeske, видів роду Anотоdon Нооk et Tayl. до Fraxinus excelsior L.
\end{abstract}

S. V. Gapon

V. G. Korolenko Poltava State Pedagogical University

\section{FREQUENCY OF BRYOPHYTES OCCURRENCE IN EPIPHYTIC COMMUNITIES}

Frequency of bryophytes occurrence in epiphytic communities of broad-leaved forests of Vorskla River valley and their ecology-biologic peculiarities are analysed. Distinct relations of bryophyte species to specific wood species are not found, while some species, i.e. Hypnum pallescens (Hedw.) P. Beauv., Platygyrium repens (Brid.) B. S. G., Bryum subelegans Kindb. are attached to Quercus robur L., but Radula complanata (L.) Dum., Leskeella nervosa (Brid.) Loeske and species of the Anomodon genus - to Fraxinus excelsior L.

\section{Вступ}

Мохоподібні - обов'язковий компонент рослинного покриву як природних, так і багатьох штучних біогеоценозів, що утворює в них більш або менш виражені бріоугруповання. Останні привертають все більше уваги дослідників, адже вони не лише $\epsilon$ об'єктом класифікації мохової рослинності, а і служать біоіндикаторами у біомоніторингових дослідженнях. Тому заслуговує на увагу комплексний підхід до їх вивчення, який включає з'ясування особливостей будови, структури, біомаси бріоугруповань, їх видового складу, частоти трапляння, проективного покриття та аналізу життєвих форм мохоподібних. Це дає можливість виявити особливості покриву мохоподібних і простежити за його динамікою. Тому метою нашої роботи і було з'ясування частоти трапляння бріофітів у досліджуваних епіфітних обростаннях, встановлення їх екологобіологічних особливостей.

Трапляння видів - фітоценологічна категорія, яка дозволяє охарактеризувати роль виду у фітоценозі [9]. Вона виражається частотою трапляння особин на пробних ділянках у відсотках до всієї кількості досліджених ділянок. Що стосується мохоподібних, цю категорію використовують не лише для з'ясування наявності виду у фітоценозі, а і для встановлення його ролі у бріоугрупованнях та утворенні мохового покриву. Залежно від поставлених завдань дослідник обирає відповідну методику визначення

(C) C. В. Гапон, 2008 
частоти трапляння [14]. У бріофлористичних дослідженнях частота трапляння переважно відображає результати суб'єктивних спостережень колектора. При цьому для ії позначення вживаються спеціальні терміни: вид масовий, спорадичний, рідкісний тощо. Такі відомості про частоту трапляння мохоподібних наводяться у більшості бріофлористичних робіт вітчизняних і зарубіжних бріологів $[2 ; 3 ; 7 ; 10]$.

У бріоценологічних дослідженнях при виявленні ролі виду в утворенні бріоугруповань та мохового покриву використовується визначення частоти трапляння за спеціальними методиками. Останні, переважно, грунтуються на встановленні частоти трапляння виду об'єктивним шляхом, а саме - відношенням кількості пробних ділянок, на яких зареєстрований вид, до загальної кількості обстежених ділянок фітоценозу. В основу таких методик покладено метод К. Раункієра, модифікований стосовно мохоподібних [14]. Так, 3. І. Мамчур [8] визначає частоту трапляння епіфітних мохоподібних у промислових містах Львівської області, С. І. Дегтярьова [6] - при дослідженні мохового компонента лісостепових дібров Середньоросійської височини. Нами також використовувалися такі методики при визначенні частоти трапляння мохоподібних в епіфітних обростаннях Парасоцького лісу [4].

\section{Матеріал і методи досліджень}

Регіоном дослідження є долина р. Ворскла в межах лісостепової зони України (частина Сумської та Полтавської областей). Оскільки зональними типами рослинності цієї зони $є$ широколистяні ліси, нами проведено збір матеріалу у дібровах, розміщених на правому крутому березі p. Ворскла та в іiі заплаві. Ця територія за геоботанічним районуванням [5] належить до Дикансько-Котельвівського (Ворсклянського) геоботанічного району кленово-липово-дубових і частково грабово-дубових та дубовососнових (на піщаних терасах) лісів Роменсько-Полтавського геоботанічного округу Лівобережнопридніпровської підпровінції, Східноєвропейської провінції, Європейсько-Сибірської лісостепової зони. Вона займає переважно розчленоване плато Ворскли, а також іiї заплавну та борову тераси. Лісова рослинність цього району, як зауважує О. М. Байрак [1], найбагатша в синтаксономічному плані, представлена ценозами всіх союзів класів Querco-Fagetea, Vaccinio-Piceetea, Salicetea purpurea, Alnetea glutinosae.

Клімат регіону дослідження помірно-континентальний, середньорічна температура повітря коливається в межах $+5,7 \ldots+6,6^{\circ} \mathrm{C}$. У грунтовому покриві на приворсклянському плато переважають чорноземи опідзолені та темно-сірі лісові грунти, а на боровій терасі - дерново-слабопідзолисті піщані та дернові піщані грунти [5]. Ліси в регіоні дослідження представлені переважно кленово-липовими та грабовими дібровами, рідше трапляються дубові ліси. У заплаві поширені вільшаники, вербняки, осокірники, рідше - заплавні діброви. Ми обстежували епіфітні обростання у нагірних кленово-липово-дубових, грабово-дубових лісах і заплавних дібровах.

Збирали матеріал на пробних ділянках, закладених у місцях із найкраще розвиненим моховим покривом. Геоботанічні описи бріоугруповань використовували для класифікації мохової рослинності за еколого-флористичною класифікацією. Усього обстежено 490 епіфітних бріоугруповань, відмічених на 14 видах дерев. Паралельно відбирали проби для визначення частоти трапляння мохоподібних. Нами використано наведений раніше [14] метод визначення частоти трапляння в епіфітних угрупованнях.

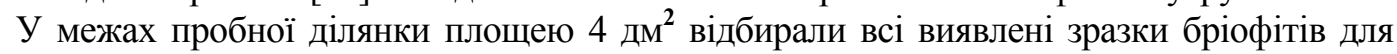
подальшої камеральної обробки. Частоту трапляння обчислювали у відсотках на одиницю площі бріоугруповання (це була відносна частота трапляння мохоподібних на одне угруповання). Відбір форофітів проводили довільно, але основними умовами бу- 
ли гомогенність у межах пробної ділянки та найкраще розвинений покрив бріофітів. Види мохоподібних подані за «Списками ...» [11-13]. Постійність видів в угрупованнях визначали за п'ятибальною шкалою постійності видів (Const.) [9]. Для реалізації поставленої мети виконували такі завдання: з'ясувати видовий склад мохоподібних, що утворювали угруповання, охарактеризувати їх еколого-біологічні особливості; виявити частоту трапляння мохоподібних; з'ясувати на основі отриманих даних ступінь приуроченості видів до певних порід дерев; проаналізувати життєві форми мохоподібних, що утворювали досліджені угруповання.

\section{Результати та їх обговорення}

Найкраще виражені епіфітні угруповання на таких породах дерев як Quercus robur L., Fraxinus excelsior L., Acer platanoides L., A. campestre L., дещо рідше вони зростають на Tilia cordata Mill., Pyrus communis L., Carpinus betulus L., Alnus glutinosa (L.) Gaertn. тощо. До складу обстежених бріоугруповань входять 46 видів мохоподібних, які належать до 2 відділів (Hepaticophyta - 4 види, Bryophyta - 42), 2 класів, 18 родин, 27 родів. Найбагатшими за кількістю видів є родини Hурпасеае (7 видів), Brachytheciaceae - 6 видів. Родини Orthotrichaceae, Amblystegiaceae репрезентовані 4 видами кожна, а Anomodontaceae - 3. Решта налічує по 1 (6 родин) або 2 (6 родин) види. У родовому спектрі також переважають роди, репрезентовані 1 (16 родів) та 1 (6 родів) видами. Лише рід Amblystegium B. S. G. налічує 6 видів, Orthotrichum Hedw. - 4, Anomodon Hook. et Tayl. i Plagiothecium B. S. G. - по 3. Серед виявлених мохоподібних, що утворювали бріоугруповання, 25 видів - облігатні епіфіти, решта - факультативні. Участь останніх в утворенні обростань на деревах імовірно можна пояснити здатністю епігейних видів уникати конкуренції з боку вищих судинних рослин, змінюючи тип субстрату, що неодноразово підкреслювалося дослідниками. Слід відзначити, що такі мохи частіше за все входять до складу угруповань прикореневої зони дерева, тобто обростають стовбур від його основи. Наявність тут ряду епіксильних видів Callicladium haldanianum, Herzogiella seligeri підкреслює їх відносну субстратну приуроченість.

Частота трапляння мохоподібних у досліджених угрупованнях досить різноманітна (табл. 1). Усі виявлені види за критерієм частоти трапляння можна поділити на п'ять груп. До першої групи відносяться мохоподібні (2 види) із найвищою частотою трапляння, яка коливається в межах від 30 до 50 \%, другої (3 види) - 20-30\%, третьої (8 видів) $10-20 \%$, четвертої (19 видів) - 1,0-10\%, п’ятої (14 видів) - нижче $1 \%$. Перша та друга групи мохоподібних представлені тільки типовими облігатними епіфітами (Pylaisia polyantha, Hypnum pallescens, Leskeella nervosa тощо). Вони мають не лише найвищу частоту трапляння, а й клас постійності (від II до III) та утворюють бріоугруповання не тільки у прикореневій, а й у стовбуровій зонах дерева. У третій групі також переважають облігатні епіфіти (Radula complanata, Anomodon longifolius, A. attenuatus, Leskea polycarpa тощо), які мають середні показники трапляння та беруть участь в утворенні бріоугруповань як прикореневої, так і стовбурової зони. У четвертій групі переважають факультативні епіфіти (11 видів), хоча участь облігатних епіфітів значна (8 видів). Останні мають у цій групі найвищі показники частоти трапляння. П'ята група бріофітів об'єднує переважно факультативні епіфіти з найнижчими показниками частоти трапляння. Хоча сюди відноситься і ряд рідкісних облігатних епіфітів, таких як Neckera complanata, Brachythecium populeum, B. reflexum. Ці види відмічені тільки в одному-двох бріоугрупованнях і мають одне-два місцезнаходження в межах дослідженого регіону. 
Відносно породної приуроченості виявлених видів мохоподібних наслідки наших досліджень показали (табл. 1) відсутність залежності частоти трапляння від конкретної породи форофіту.

Таблиия 1

Частота трапляння мохоподібних в епіфітних обростаннях Полтавської області

\begin{tabular}{|c|c|c|c|c|}
\hline № & Види мохоподібних & $\begin{array}{c}\text { Частота } \\
\text { трапляння, \% }\end{array}$ & $\begin{array}{c}\text { Кількість порід, } \\
\text { на яких оселяється вид, \% }\end{array}$ & Const. \\
\hline 1 & Hypnum pallescens (Hedw.) P. Beauv. & 43,9 & 85,7 & II \\
\hline 2 & Platygyrium repens (Brid.) B. S. G. & 30,4 & 64,2 & II \\
\hline 3 & Pylaisia polyantha (Hedw.) Schimp. & 29,6 & 85,7 & II \\
\hline 4 & Bryum subelegans Kindb. & 28,5 & 57,1 & II \\
\hline 5 & Leskeella nervosa (Brid.) Loeske & 27,1 & 42,9 & II \\
\hline 6 & Radula complanata (L.) Dum. & 18,7 & 42,9 & II \\
\hline 7 & Brachythecium velutinum (Hedw.) B. S. G. & 18,0 & 71,4 & I \\
\hline 8 & Anomodon longifolius (Brid.) Hartm. & 16,5 & 28,6 & $\mathrm{I}$ \\
\hline 9 & Amblystegium serpens (Hedw.) B. S. G. & 15,1 & 57,1 & I \\
\hline 10 & Anomodon attenuatus (Hedw.) Hüb. & 14,7 & 28,6 & I \\
\hline 11 & Leskea polycarpa Hedw. & 14,2 & 71,4 & I \\
\hline 12 & Brachythecium salebrosum (Web. et Mohr.) B. S. G. & 11,6 & 71,4 & I \\
\hline 13 & Platydictya subtilis (Hedw.) Crum. & 11,4 & 28,6 & I \\
\hline 14 & Hypnum cupressiforme Hedw. & 8,4 & 71,4 & I \\
\hline 15 & Leucodon sciuroides (Hedw.) Schwaegr. & 7,3 & 42,9 & $\mathrm{I}$ \\
\hline 16 & Lophocolea heterophylla (Schrad.) Dum. & 4,3 & 35,7 & I \\
\hline 17 & Orthotrichum pallens Bruch et Brid. & 4,5 & 64,3 & I \\
\hline 18 & Plagiothecium denticulatum (Hedw.) B. S. G. & 4,2 & 35,7 & I \\
\hline 19 & Orthotrichum speciosum Nees. & 3,9 & 50 & $\mathrm{I}$ \\
\hline 20 & Plagiothecium laetum B. S. G. & 1,8 & 14,3 & I \\
\hline 21 & Anomodon viticulosus (Hedw.) Hook et Tayl. & 1,6 & 28,6 & I \\
\hline 22 & Plagiothecium nemorale (Mitt.) Jaegr. & 1,6 & 28,6 & I \\
\hline 23 & Plagiomnium cuspidatum (Hedw.) T. Kop. & 1,6 & 21,4 & I \\
\hline 24 & Orthotrichum pumilum Sw. & 1,4 & 28,6 & $\mathrm{I}$ \\
\hline 25 & Callicladium haldanianum (Grev.) Crum. & 1,4 & 28,6 & I \\
\hline 26 & Porella platyphylla (L.) Pfeiff. & 1,4 & 21,4 & I \\
\hline 27 & Amblystegium varium (Hedw.) Lindb. & 1,4 & 21,4 & I \\
\hline 28 & Tortula ruralis (Hedw.) Gaertn. & 1,4 & 14,3 & I \\
\hline 29 & Dicranum montanum Hedw. & 1,2 & 28,6 & $\mathrm{I}$ \\
\hline 30 & Brachythecium oedipodium (Mitt.) Jaegr. & 1,2 & 21,4 & $\mathrm{I}$ \\
\hline 31 & Plagiothecium succulentum (Wils.) Lindb. & 1,2 & 21,4 & I \\
\hline 32 & Bryum capillare Hedw. & 1,0 & 21,4 & I \\
\hline 33 & Dicranum viride (Sull. et Lesg.). Lindb. & 0,6 & 14,2 & I \\
\hline 34 & Homalia trichomanoides (Hedw.) B. S. G. & 0,6 & 14,2 & I \\
\hline 35 & Ceratodon purpureus (Hedw.) Brid. & 0,4 & 14,2 & $\mathrm{I}$ \\
\hline 36 & Orthotrichum affine Brid. & 0,4 & 14,2 & I \\
\hline 37 & Brachythecium reflexum (Starke) B. S. G. & 0,4 & 14,2 & $\mathrm{I}$ \\
\hline 38 & Lophocolea minor Nees & 0,2 & 7,1 & I \\
\hline 39 & Plagiomnium ellipticum (Brid.) T. Kop. & 0,2 & 7,1 & I \\
\hline 40 & Neckera complanata (Hedw.) Hüb. & 0,2 & 7,1 & $\mathrm{I}$ \\
\hline 41 & Pterigynandrum filiforme Hedw. & 0,2 & 7,1 & I \\
\hline 42 & Leptodyctium riparium (Hedw.) Warnst. & 0,2 & 7,1 & I \\
\hline 43 & Sanionia uncinata (Hedw.) Loeske & 0,2 & 7,1 & I \\
\hline 44 & Brachythecium populeum (Hedw.) B. S. G. & 0,2 & 7,1 & I \\
\hline 45 & Brachythecium rivulare B. S. G. & 0,2 & 7,1 & I \\
\hline 46 & Herzogiella seligeri (Brid.) Iwats. & 0,2 & 7,1 & I \\
\hline
\end{tabular}

Примітка: Const. - постійність видів; I, II, III - класи постійності видів за п’ятибальною шкалою [9]. 60 
Види мохів, які мають досить високу частоту трапляння, відмічені на багатьох породах. Це Pylaisia polyantha, Hypnum pallescens (на 12 породах), Brachythecium salebrosum, B. velutinum, Hypnum cupressiforme (на десяти). Типові епіфіти Radula complanata, Bryum subelegans, Leskeella nervosa, Leucodon sciuroides, Orthotrichum pallens, O. speciosum, Platygyrium repens відмічені на 6-9 породах дерев. Як відомо, чіткої приуроченості бріофітів до конкретних порід дерев немає, але, судячи з наших досліджень (на основі частоти трапляння), можна зауважити про наявність певного тяжіння окремих видів до окремих порід дерев. Так Hypnum pallescens, Platygyrium repens, Bryum subelegans найчастіше зустрічаються на Quercus robur, a Anomodon longifolius, A. attenuatus, Leskeella nervosa, Radula complanata - на Fraxinus excelsior. Досить індиферентною до вибору породи є Pylaisia polyantha, яка зростає більш або менш рівномірно на багатьох породах. Низьку частоту трапляння типових облігатних епіфітів Porella platyphylla, Brachythecium populeum, B. reflexum, Homalia trichomanoides, Neckera complanata, Pterigynandrum filiforme можна, ймовірніше за все, пояснити значним ступенем трансформованості лісових масивів цього регіону.

Найбагатшим є видовий склад бріоугруповань Quercus robur, Fraxinus excelsior та Acer platanoides (рис. 1.) На цих же породах епіфітні обростання також і найрозвиненіші. Дещо менше видів виявлено у складі обростань на A. campestre, Tilia cordata, Pyrus communis, Carpinus betulus, Alnus glutinosa. На інших досліджених породах (Betula pendula Roth., Crataegus curvisepala Lindb., Salix alba L., Populus alba L., P. nigra L., $P$. tremula L.) виявлена незначна кількість видів. Це, насамперед, можна пов'язати 3 низькою часткою цих порід в утворенні досліджених деревостанів.

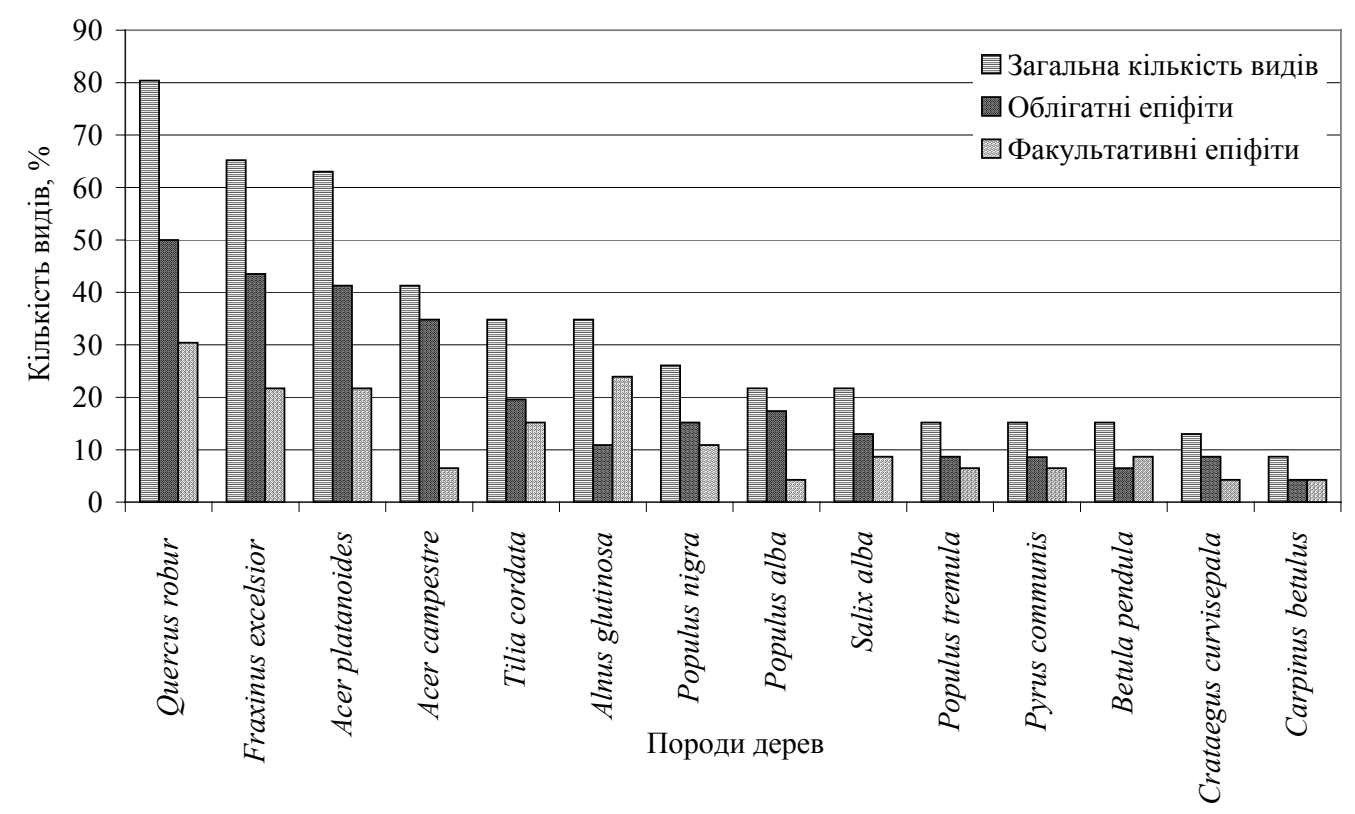

Рис. 1. Розподіл видів мохоподібних за породами дерев в умовах долини р. Ворскла (у межах Полтавської та Сумської областей).

Простежуючи частоту трапляння мохоподібних в епіфітних обростаннях, ми з'ясовували їх еколого-біологічні особливості (належність до різних типів екоморф і життєвих форм). У результаті таких досліджень виявлено (рис. 2), що у складі досліджених угруповань переважають види 3 життєвою формою плоский килим (25 видів, 54,3 \%). Решта видів мохоподібних мають вертикально-галузистий килим (5 видів, 
$10,9 \%$ ), подушечки (4 - 8,7 \%), низькі та високі дернинки (по 3 - по 6,5 \%), плетиво, низькі подушковидні дернинки та нитковидний килим (по 2 - по 4,3 \%). Таку перевагу у бріоугрупованнях плоскокилимових видів, очевидно, можна пояснити високим ступенем пристосованості цієї життєвої форми до епіфітного способу життя. Адже мохоподібні з такою життєвою формою мають більше шансів уникнути коливання струменів повітря і краще використовують вологу, що стікає по стовбуру. Ті ж види, яким властиві високі дернинки та плетиво, переважно входять до складу угруповань, що формуються в основі стовбурів дерев.

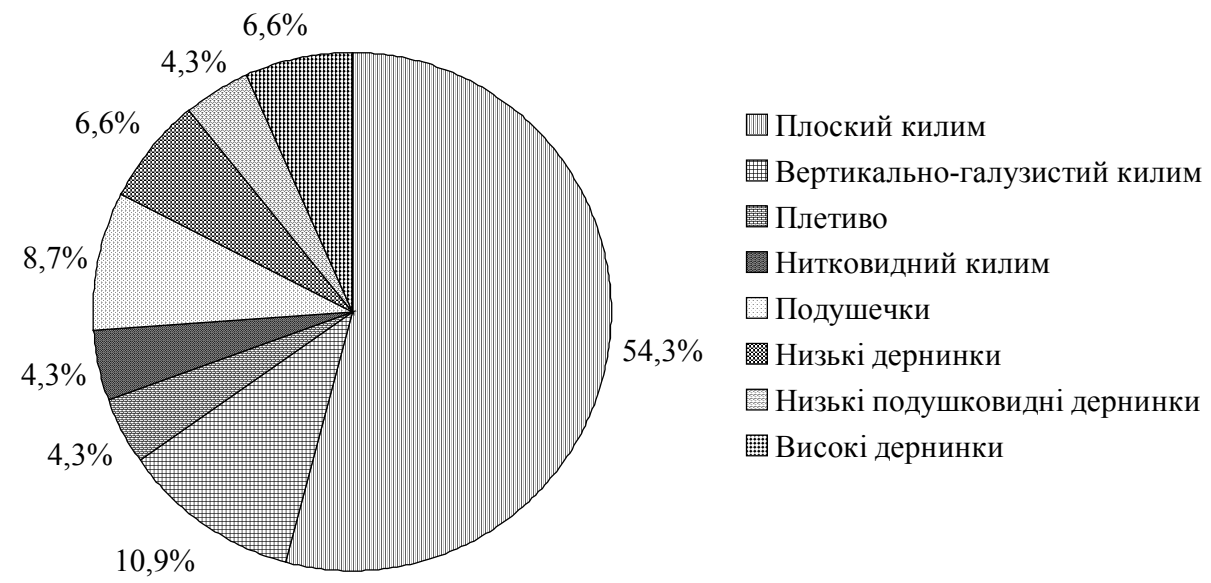

Рис. 2. Співвідношення життєвих форм мохоподібних у епіфітних обростаннях долини р. Ворскла (у межах Полтавської та Сумської областей).

За відношенням до вологи серед виявлених видів переважають мезофіти (23 види, $50 \%$ ), ксерофіти та мезоксерофіти, представлені 8 та 9 видами (відповідно 17,4 та 19,6 \%). Частка мезогігро-, гігро-, гідрофітів та індиферентних видів незначна.

За відношенням до світла переважають геліосціофіти та сціофіти - відповідно 20 (43,4 \%) та 21 (45,7 \%) вид. Частка індиферентних і світлолюбних видів незначна.

Більш різноманітними $є$ екоморфи мохоподібних за відношенням до $\mathrm{pH}$ субстрату. Серед них виявлені базифіли (10 видів - 21,7 \% ), нейтрофіли (11 видів - 23,9\%), ацидонейтрофіли $(7-15,2 \%)$, ацидофіли (1 вид - 2,2 \%). Переважають у цій групі екоморф індиферентні види (17 видів - 37,0 \%).

\section{Висновки}

Епіфітний моховий покрив широколистяних лісів долини р. Ворскла добре розвинений. Бріоугруповання, що його утворюють, досить багаті за видовим складом. Переважають типові епіфіти, які і мають найвищу частоту трапляння. Низька частота трапляння характерна для більшості факультативних епіфітів. Про значний ступінь трансформованості досліджених деревостанів свідчить низька частота трапляння типових епіфітів, таких як Frulania dilatata, Porella platyphylla, Homalia trichomanoides, Neckera complanata, Pterigynandrum filiforme. Чіткої приуроченості бріофітів до певних порід дерев не спостерігається. Але все ж певне тяжіння деяких видів (Hypnum pallescens, Leskeella nervosa, Platygyrium repens, Radula complanata) є характерним. Комплексне вивчення бріоугруповань може бути розширене за рахунок аналізу проективного покриття мохоподібних в угрупованнях. 


\section{Бібліографічні посилання}

1. Байрак О. М. Особливості рослинності фітоценохоріонів Лівобережного Придніпров'я // Зб. наук. праць Полтавського держ. пед. ун-ту ім. В. Г. Короленка. Екологія. Біологічні науки. - Вип. 6 (58). - Полтава, 2007. - С. 3-10.

2. Вирченко В. М. Мохообразные лесостепной части Приднепровской возвышенности (конспект флоры) / Ред. Укр. ботан. журн. - К., 1989. - 60 с.; Деп. в ВИНИТИ 03.01.89, № $84 .-$ B. 89.

3. Гапон С. В. Конспект бріофлори Лівобережного Лісостепу України. - Полтава: Полтав. держ. пед. ін-т, 1997. - 37 с.; Деп. в ДНТБ Укр. 04.01.98, № 2. - Ук. 98.

4. Гапон С. В. Мохоподібні епіфітних обростань Парасоцького лісу // Укр. ботан. журн. 1989. - Т. 46, № 5. - С. 55-58.

5. Геоботанічне районування Української РСР. - К.: Наук. думка, 1977. - С. 172-179.

6. Дегтярева С. И. Моховой компонент лесостепных дубрав и его использование для оценки состояния екосистем: Автореф. дис. ... канд. биол. наук. - Воронеж, 2004. - 23 с.

7. Железнова Г. В. Флора листостебельных мхов Республики Коми: Автореф. ... дис. д-ра биол. наук. - Сыктывкар: 2000. - 47 с.

8. Мамчур 3. І. Епіфітні мохоподібні промислових міст Львівської області / Автореф. дис. ... канд. біол. наук. - К., 1997. - 22 с.

9. Миркин Б. М. Словарь понятий и терминов современной фитоценологии / Б. М. Миркин, Г. С. Розенберг, Л. Г. Наумова. - М.: Наука, 1989. - 220 с.

10. Попова Н. Н. Бриофлора Среднерусской возвышенности // Arctoa. - 2002. - № 11. C. 101-168.

11. Список печіночників, антоцеротів та сфагнових мохів України / Уклад. В. М. Вірченко, I. Ваня. - К.: Знання, 2000. - 29 с.

12. Список верхоплідних мохів України / Уклад. В. М. Вірченко. - К.: Знання, 2001. - 56 с.

13. Список бокоплідних мохів України / Уклад. В. М. Вірченко. - К.: Знання, 2000. - 32 с.

14. Улычна К. О. К методике изучения эпифитных моховых обрастаний / К. О. Улычна, С. В. Гапон, Т. Г. Кулик // Проблемы бриологии в СССР. - Л.: Наука, 1989. - С. 201-206.

Надійшла до редколегї̈ 08.07.2007 